\title{
A GENERALIZATION OF DARBO'S FIXED POINT THEOREM WITH AN APPLICATION TO FRACTIONAL INTEGRAL EQUATIONS
}

\author{
Said Beloul, M. Mursaleen* And Arslan Hojet Ansari
}

Abstract. In this paper, we give a new generalization of Darbo's fixed point theorem of integral type. An application for the solvability of nonlinear fractional integral equation is given to illustrate our result.

Mathematics subject classification (2020): 47H08, 47H10. equation.

Keywords and phrases: Fixed point, measure of noncompactness, Darbo's theorem, fractional integral

\section{REFERENCES}

[1] R. P. Agarwal, M. Meehan and D. O'Regan, Fixed Point Theory and Applications, Cambridge University Press, Cambridge, 2004.

[2] R. P. AGARWAL AND B. SAMET, An existence result for a class of nonlinear integral equations of fractional orders, Nonlin. Anal, Model. Cont, 21(5) (2016) 716-729.

[3] A. Aghajania And M. Alias Kari, Generalization of Darbo's fixed point theorem and application, IJNAA, 2(2011) 86-95.

[4] A. Aghajani, J. Banaś And N. SAbZali, Some generalizations of Darbo fixed point theorem and applictions, Bull. Belg. Math. Soc. Simon Stevin, 20 (2013) 345-358.

[5] A. Aghajani, R. Allahyari And M. Mursaleen, A generalization of Darbo's theorem with application to the solvability of systems of integral equations, J. Comput. Appl. Math., 260, (2014) 68-77.

[6] A. H. ANSARI, Note on $\varphi-\psi$-contractive type mappings and related fixed point, The 2 nd Regional Conference on Mathematics and Appl., 2014 (2014) 377-380.

[7] J. BAnaś, On measures of noncompactness in Banach spaces, Comment. Math. Univ. Carolinae, 21 (1980) 131-143.

[8] J. BANAŚ, Measures of noncompactness in the study of solutions of nonlinear diferential and integral equations, Cent. Eur. J. Math., 10 (6) (2012), 2003-2011.

[9] J. BAnaś AND K. GoeBel, Measures of noncompactness in Banach spaces, in: Lecture Notes in Pure and Applied Mathematics, Vol. 60, Marcel Dekker, New York, 1980.

[10] L. CAi And J. Liang, New generalizations of Darbo's fixed point theorem, Fixed Point Theory and Applications (2015) 2015: 156.

[11] G. Darbo, Punti uniti in transformazioni a condominio non compatto, Rend. Sem. Math. Univ. Padova, 2 (1955) 84-92.

[12] I. T. Gohberg, L. S. Goldenštein AND A. S. Markus, Investigation of some properties of hounded linear operators in connection with their q-norms, Učen. Zap. Kishinevsk. Univ., 29 (1957) 29-36.

[13] M. Jleli, E. Karapinar, D. O'Regan And B. Samet, Some generalizations of Darbo's theorem and applications to fractional integral equations, Fixed Point Theory and Applications (2016) 2016: 11.

[14] M. Jleli, M. Murs aleEn And B. Samet, Q-integral equations of fractional orders, Elect. J. Diff. Eq, Vol. 2016 (17), (2016) 1-14.

[15] K. KURatows Ki, Sur les espaces complets, Fund. Math. 5 (1930), 301-309. 
[16] S. A. Mohiuddine, H. M. SRivastava And A. Alotaibi, Application of measures of noncompactness to the infinite system of second-order differential equations in $\ell_{p}$ spaces, Adv. Difference Equ. (2016) 2016:317.

[17] M. Murs aleen, B. Bilalov and S. M. H. Rizvi, Applications of measures of noncompactness to infinite system of fractional differential equations, Filomat, 31 (11) (2017) 3421-3432.

[18] M. Mursaleen And S. M. H. Rizvi, Solvability of infinite system of second order differential equations in $c_{0}$ and $\ell_{1}$ by Meir-Keeler condensing operator, Proc. Amer. Math. Soc., 144 (10) (2016) 4279-4289.

[19] A. Samadi, M. M. Avini And M. Mursaleen, Solutions of an infinite system of integral equations of Volterra-Stieltjes type in the sequence spaces $\ell_{p}(1<p<1)$ and $c_{0}$, AIMS Mathematics, 5 (4) (2020) 3791-3808.

[20] A. Samadi And M. B. Ghaemi, An extension of Darbo fixed point theorem and its applications to coupled fixed point and integral equations, Filomat 28 (4), (2014) 879-886.

[21] H. M. Srivastava, A. Das, B. Hazarika And S. A. Mohiuddine, Existence of solution for non-linear functional integral equations of two variables in banach algebra, Symmetry 11 (2019), Article 674.

[22] H. M. SRivastava, A. Das, B. Hazarika And S. A. Mohiuddine, Existence of solutions of infinite systems of differential equations of general order with boundary conditions in the spaces $c_{0}$ and $\ell_{1}$ via the measure of noncompactness, Math. Meth. Appl. Sci. 41 (2018) 3558-3569. 